\section{OUTCOME BASED LEARNING: THE EFFECT OF EXPERIENTIAL LEARNING ACTIVITIES ON THE ATTAINMENT OF SPECIFIC LEARN- ING OUTCOME AMONG SENIOR SECONDARY SCHOOL STUDENTS}

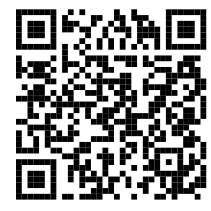

\author{
Prashant Thote $^{1}{ }^{\square}$ and Gowri $\mathrm{S}^{1}$ \\ ${ }^{1}$ Gyanodaya Vidya Mandir, India
}

Received 21 March 2021

Accepted 6 April 2021

Published 30 April 2021

Corresponding Author

Prashant Thote, thote@rediffmail. com

DOI 10.29121/

granthaalayah.v9.i4.2021.3824

Funding: This research received no specific grant from any funding agency in the public, commercial, or not-for-profit sectors.

Copyright: (C) 2021 The Author(s). This is an open access article distributed under the terms of the Creative Commons Attribution License, which permits unrestricted use, distribution, and reproduction in any medium, provided the original author and source are credited.

\section{ABSTRACT}

Experiential learning activity is a group activity in which the role of an individual is well defined and central focus is on the process and not the outcome. Its process, steps, as well as the content involves active participation of both learners and teachers to attain intended specific learning outcome. In this present paper efforts are made to investigate the impact of experiential learning activity in germinating interests among the students in Chemistry and also to study the co-relation between the interest in studying Chemistry and their academic achievement. The study is conducted during the academic session 2020-2021. Random sampling method is used to draw the sample. Totally 50 students participate in the study. Sample consists of 25 boys and 25 girls. Sample is categorized into the study and the control group. Both groups are taught the unit "Redox Reaction" by traditional lecture method but the study group is exposed to the experiential learning activity designed for the experimental redox reaction. Data is collected by using two questionnaires. Students Interest Test (SIT) and Chemistry Performance Test (CPT) are administrated. Reliability of Students Interest Test (SIT) is done Cronbach Alpha test and found to be 0.86 and reliability test for Chemistry Performance Test by Richardson 21 formula and found to be 0.76 . Hybrid research designs such as quasi experiment and survey are applied to collect the data. Data is collected by using pre-test and post-test. The collected data is analyzed by using statistical tools such as independent ttest and Pearson Product Movement to study the co-relation co-efficient. The result of the present study has noteworthy difference of 0.87 significant at 0.05 level. Result of the present paper reveals that the experiential learning activity designed for experimental redox reaction enhances the students' interest in learning chemistry and has a positive correlation in enhancing their academic performance to attain the specific learning outcomes.

Keywords: Redox Reaction, Interest, Experiment, Experiential Learning, Hands-On Activity 


\section{INTRODUCTION}

"Tell me I forget, Teach me I may remember, Involve me and I learn" - Benjamin Franklin

Education must focus on the holistic development of the child and is based on experiential learning. Education is effective when it is transacted through craft and work. Education is for character building and focuses on values and ethics. Work is curricular and not co-curricular or extra-curricular activity. School must keep science at the centre and not as a knowledge shop. In school, knowledge is generated through curriculum which focuses on culture, art, music, dance and sports. It catalyzes imagination and creativity for peaceful living and harmony. Experiential learning is an application of knowledge and theory to real life experience. It fosters attainment of specific learning outcomes and encourages reflection and application of skills and knowledge and prepares future citizen for productive life. Experiential learning:

- Integrates with direct experience and focus on reflection.

- Is constructed on previous knowledge and experience.

- Requires active involvement in constructions.

- Encourages, exchanges and collaborate ideas and perspectives.

- Takes place in classroom, workplace and community.

The essential conditions that are required to ensure effective association of experiential learning experience with education are:

1. Activities that are supported by reflection, critical analysis and synthesis.

2. Activities that require students' initiative, decision making skills and their accountability for results.

3. Students' participation in posing questions, investigations, experimentations, their curiosity, problem solving skills, assuming responsibly, creativity and constructively.

Participation of students (physically, socially, emotionally and intellectually) is important for converting hands-on activity to minds-on activity. There is wide range of design model that aims to embed learning with real world context such as:

1. Laboratory and workshops

2. Apprenticeship

3. Problem based learning

4. Case based learning

5. Project based learning

6. Enquiry based learning

7. Co-operative learning. 


\section{Field visit/Industrial visit}

Redox reaction is an important concept in chemical system at senior secondary school. Redox reaction is an electron book keeping process that involves transfer of electors form one species that is reducing agent or reducent to another species that is oxidizing agent or oxidant, leading to changes in electrical charges of species involved in the reaction. It provides framework within which chemical similarities are recognized and chemical properties are corelated. Redox reaction provides formidable and unique challenges to the learners.

Students' knowledge about oxidation and reduction reaction is categorized by the lack off or absence off coherence. Student do not possess well-founded basic framework regarding redox reaction and newly acquired experience may be integrated. In a chemical process redox reaction is considered as elementary because in such reaction's elements are changed chemically. Hence sound and deep conceptual understanding is inevitable as per the human kind appreciate the reactions such as combustion of fuel (oil), photosynthesis in plants, respiration in living organism, metabolism of fat in body, operation of battery etc.,

In $21^{\text {st }}$ century globe is advancing at extraordinary pace. Many teachers who are teaching Science integrate with intermitting demonstration of experiences. Their focus is on understanding the concept and application of those concepts in real life situations. Science is an abstract subject which gives way to the perception of scientific concepts such as human construct from the real-life situation.

The transformation in education has been overwhelming and there is paradigm shift form behaviouristic approach to constructivism that underpins the outcomebased learning. The role of the students and teachers are crucial and it is the heart of the dynamic system of education. The concept of vulnerable old master is hard to sustain in the current educational context of new curriculum and methodologies. Teachers need to track the student to navigate through their development along with the learning of curriculum. Feedback is an essential component and it must be encouraging, motivating, be positive, constructive and critical towards better improvement. The positive climate during the classroom instruction provides better participation in learning process.

Experiential learning activity for teaching redox reaction is a part of senior secondary school curriculum. Experiential learning activity is premeditated to demonstrate and to illustrate the chain of redox reaction - it is a colour changing demonstration experiment.

\section{Oxidizing Agent and Reducing Agent}

Redox reaction is a chemical reaction in which ions, atoms or molecules loss or gain electrons, alternating its oxidation state. An oxidising agent gains electron and reduce in reaction. On the other hand, reducing agents lose its electron and get oxides in the reaction. In the present experiment glucose is used as a reducing agent. A solution containing $\mathrm{OH}^{-}$ion is taken and glucose is added to that solution. Number of half reactions take place - in one of the reactions aldehyde (-CHO) group in glucose 
donate electrons. As a result, carboxylic group $(-\mathrm{COOH})$ is present in the form of carboxylate ion $\left(-\mathrm{COO}^{-}\right)$which is present in alkaline medium. The ensuing reactions occur:

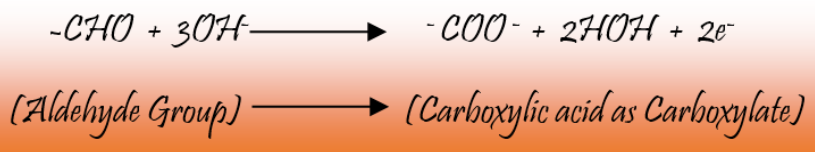

Primary alcoholic group of glucose donate electrons and produce carboxylate ion and secondary alcoholic group produce Ketone group and the following reaction takes place.

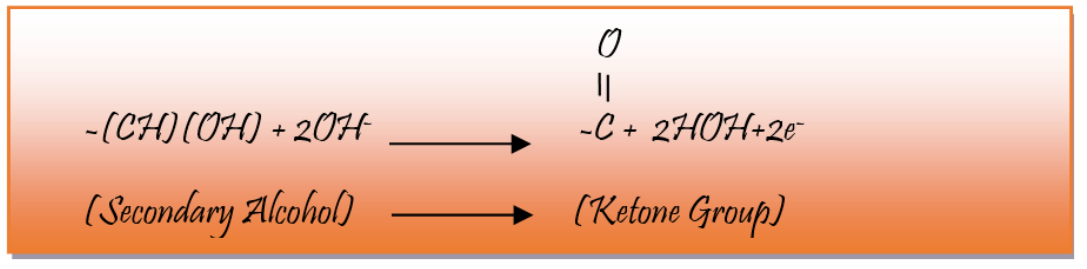

In experiential learning activity glucose is added to permanganate solution $\mathrm{KMnO}_{4}$ along with sodium hydroxide $(\mathrm{NaOH})$. Electron is donated from glucose to permanganate solution $\left(\mathrm{MnO}_{4}{ }^{-}\right)$. In these redox reactions Gluconic acid $\left(\mathrm{C}_{6} \mathrm{H}_{10} \mathrm{O}_{7}\right)$ is the major product and during Oxidation of reducing sugar - D-Ribonic acid $\left(\mathrm{C}_{5} \mathrm{H}_{10} \mathrm{O}_{6}\right)$ and dioxirane acid $\left(\mathrm{CH}_{2} \mathrm{O}_{2}\right)$ are formed as a by-product. Lollipop is considered as a source of reducing sugar- if it contains fructose in place of glucose then the major product of oxidation is frutonic acid $\left(\mathrm{C}_{6} \mathrm{H}_{10} \mathrm{O}_{7}\right)$ in place of carbonic acid

In present redox reaction electrons are donated continuously form glucose to successive compounds of manganese. As it is a chain reaction at each step colour change is visible. Manganese is the most ideal element for experiential learning activity to understand experimental redox reaction as it has more stable oxidation state other than transmission metal from $(+2$ to +7$)$. Each oxidation state has different colour.

Materials required for experiential learning activity for experimental redox reaction

1. Crystals of potassium permanganate $\left(\mathrm{KMnO}_{4}\right)$

2. Source of glucose is lollipop $\left(\mathrm{C}_{6} \mathrm{H}_{12} \mathrm{O}_{6}\right)$ (source of reducing agent)

3. Alkaline medium - pallets of sodium hydroxide $(\mathrm{NaOH})$ as medium $0.5 \mathrm{~g}$ approx.

4. Distilled water $250 \mathrm{ml}$

5. Conical flask and beaker $(500 \mathrm{ml})$

6. Spatula

7. Adhesive tape

8. Minatare of electrical whisk (hand held milk fortes) 


\section{Procedure}

The activity is planned for one lesson of 45 minutes duration at Chemistry lab. The experiential learning activity for experimental redox reaction is conducted by the following ways:

1. Fill the $250 \mathrm{ml}$ clean conical flask with $200 \mathrm{ml}$ of distilled water carefully.

2. Add $0.5 \mathrm{~g}$ of sodium hydroxide $(\mathrm{NaOH})$ pallet to $200 \mathrm{ml}$ of distilled water.

3. Stir the solution till it dissolves completely.

4. Add few crystals of potassium permanganate $\left(\mathrm{KMnO}_{4}\right)$ carefully with the help of spatula (Adding too many crystals will make the colour of solution too dark and change in colour may not be visible). Potassium permanganate $\left(\mathrm{KMnO}_{4}\right)$ added to alkaline solution $(\mathrm{NaOH})$ will ionize into potassium $\left(\mathrm{K}^{+}\right.$ion $)$and permanganate $\left(\mathrm{MnO}_{4}{ }^{-}\right.$ion $)$.

5. Attach the sticks of unwrapped lollipop by using adhesive tape as shown in fig 1 to the mini electrical whisk.

6. Insert the rods of lollipop as a reducing sugar agent into alkaline potassium permanganic solution and switch on the whisk to start the mixing.

$$
\mathrm{KXnO}_{4} \text { (aq) } \longrightarrow \mathrm{K}_{(\text {aq })}+\mathrm{XnO}_{4}^{-} \text {(aq) }
$$

As glucose dissolve into the solution containing manganese ion $\left(\mathrm{MnO}_{4}{ }^{-1}\right)$ as per fig 2 , five different colours are seen and each colour represents each manganese state of oxidation $(+2$ to +7$)$

- The first colour: purple represents permanganate ion $\left(\mathrm{MnO}_{4}{ }^{-}\right)$in +7 oxidation state of manganese.

- The change in colour from purple to green : Green is second colour. The permanganate ion $\left(\mathrm{MnO}_{4}{ }^{-1}\right)$ reduces to manganate ion $\left(\mathrm{MnO}_{4}{ }^{-2}\right)$. During this stage manganese change from +7 to +6 oxidation state

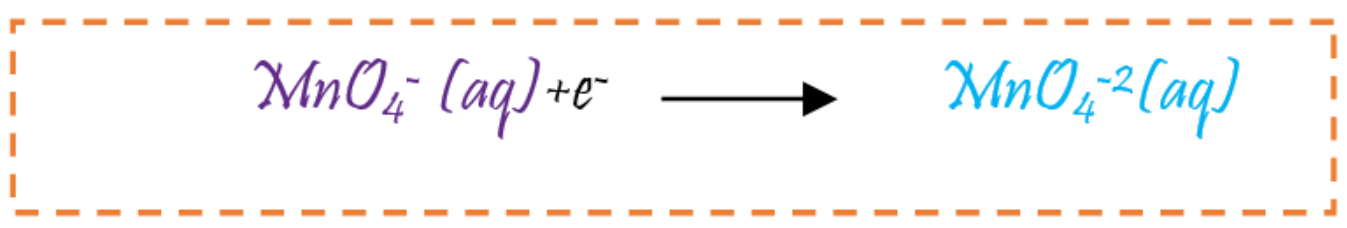

- The change in colour from green to blue: At stage one when oxidation changes from +7 to +6 intermediate blue colour is observed. 
Hypothesis 1: It may be due to the mixture of purple colour $\left(\mathrm{MnO}_{4}{ }^{-}\right)$and green colour $\left(\mathrm{MnO}_{4}{ }^{-2}\right)$.

Hypothesis 2: It may be due to the part of permanganate ion $\left(\mathrm{MnO}_{4}{ }^{-}\right)$which reduces to hypomanganate $\left(\mathrm{MnO}_{4}{ }^{-3}\right)$ and has +5 oxidation state (blue in colour).

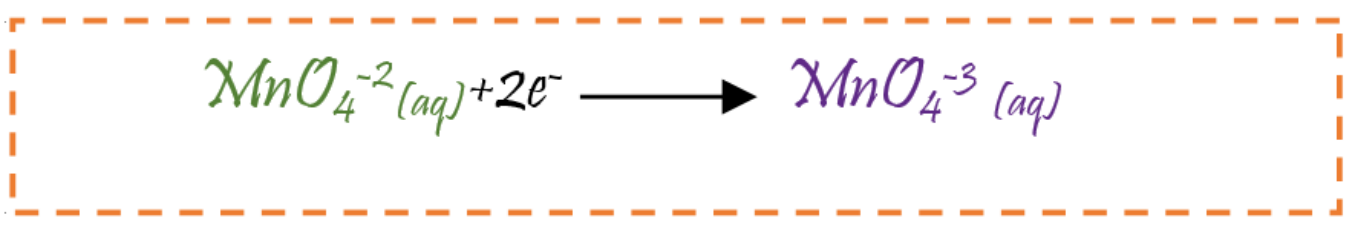

Change from green to brown yellow: Manganate ion $\mathrm{MnO}_{4}{ }^{-2}$ has +6 oxidation state reduces to manganese dioxide $\left(\mathrm{MnO}_{2}\right)$ in +4 oxidation state causing change in colour from green to brown yellow.

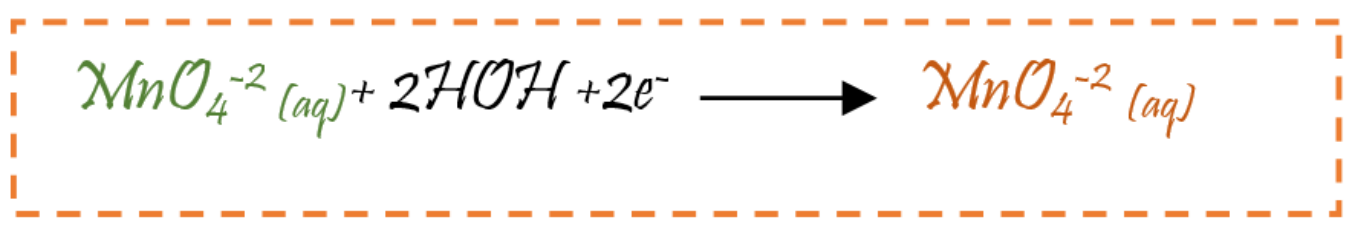

- By adding more glucose to the solution, solution is converted into colloidal suspension of manganese dioxide $\left(\mathrm{MnO}_{2}\right)$ which is in the form of alkaline solute (precipitation) which is seen in Orange colour.

\section{Colour spectrum}

The food colour is added when making lollipop and that has no major impact on the colour spectrum produced during experiential learning activity designed for experimental redox reaction. Once the redox reaction is commenced there is always a mixture of ions in the solution resulting in mixture of colour that is not easy for accurate interpretation and inferences.

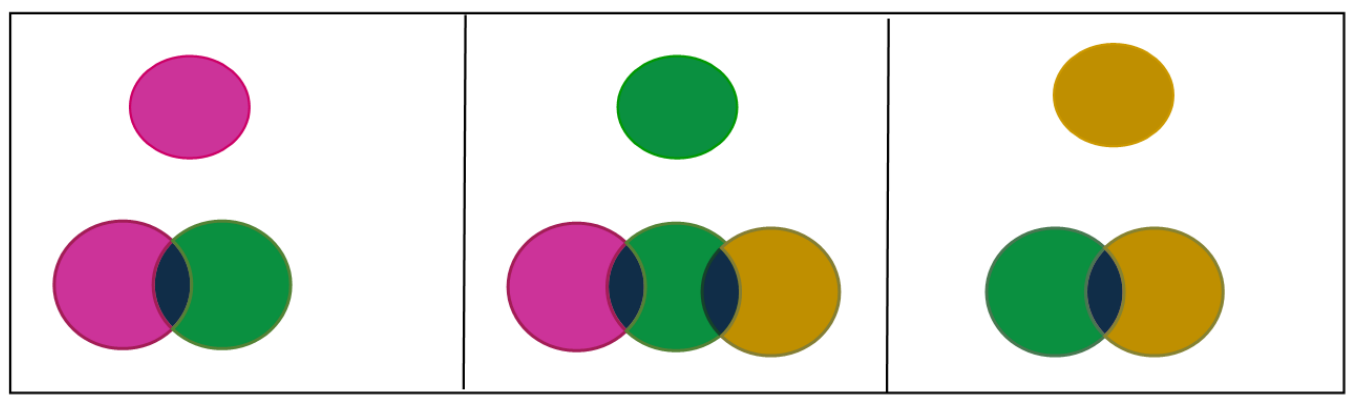

Figure 1 
The another factor that is related to the colour of manganese ion in the solution is mostly

different from the colour corresponding to its solid state. It may be due to the development of complex salt of Manganese with water due to electron accepting capacity of vacant atomic de-orbital. The tendency to gain electrons varies with temperature and $\mathrm{pH}$ of the solution. Colour change depends upon the change in these variables such as concentration of reaction, temperature and the $\mathrm{pH}$ of the medium used for conducting reaction. Colour will vary and change in colour occurs at different times during the experiment.

\section{Transmission Metals and Its Electronic Configuration}

Electrons are organized in shells based on their energy levels. Each shell is further divided into subshells and is made up of orbitals. In transition metals de- orbitals contain one or more electrons. The energy level between the electrons of de- orbitals is very small. Hence all transition metals cations have broad ways to form chemical bonds involving number of electrons from de- orbitals. Hence transition metals exhibit variable oxidation state.

On absorbing electron magnetic radiations electron jumps from lower energy level to higher energy level. In most of the transition metal energy varies between the two levels of orbitals equivalent to the energy of radiation in the visible spectrum of light. Electrons from de- orbital of permanganate ions $\left(\mathrm{MnO}_{4}{ }^{-}\right)$absorbs electromagnetic radiation from yellow part of the visible spectrum but in the experiential learning activity for experimental redox reaction the colour of permanganate ions is complementary (purple colour). As per the Figure 4 the colour of the remaining wavelength is not absorbed. After the experiment, the teacher raises the following questions to check the level of deep conceptual understating and the attainment of specific learning outcomes.

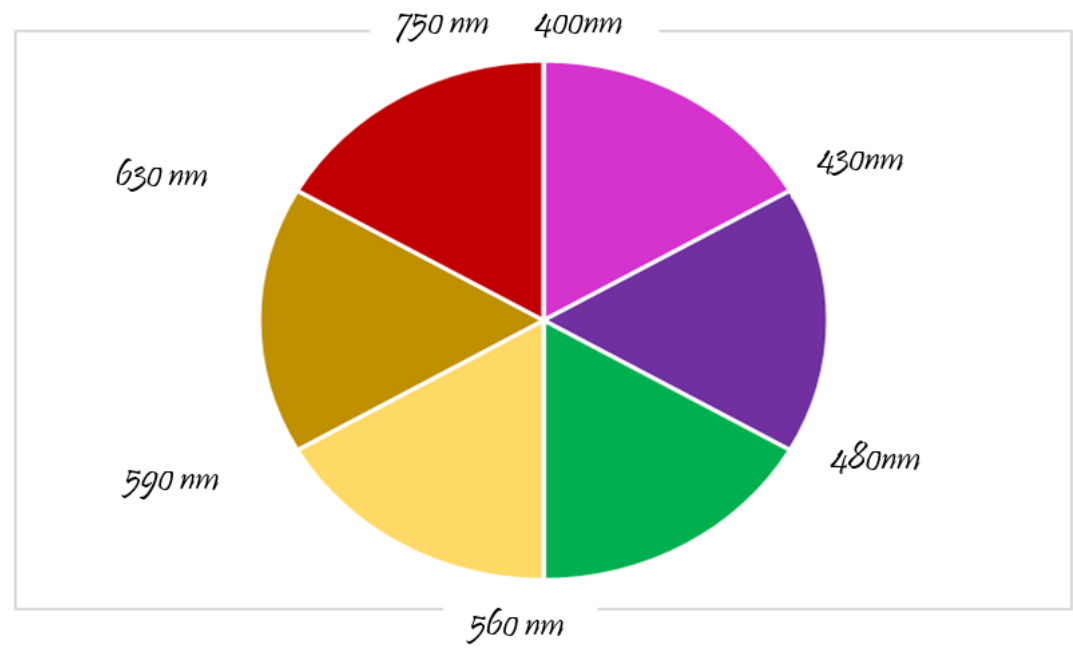

Figure 2 Complementary colours 

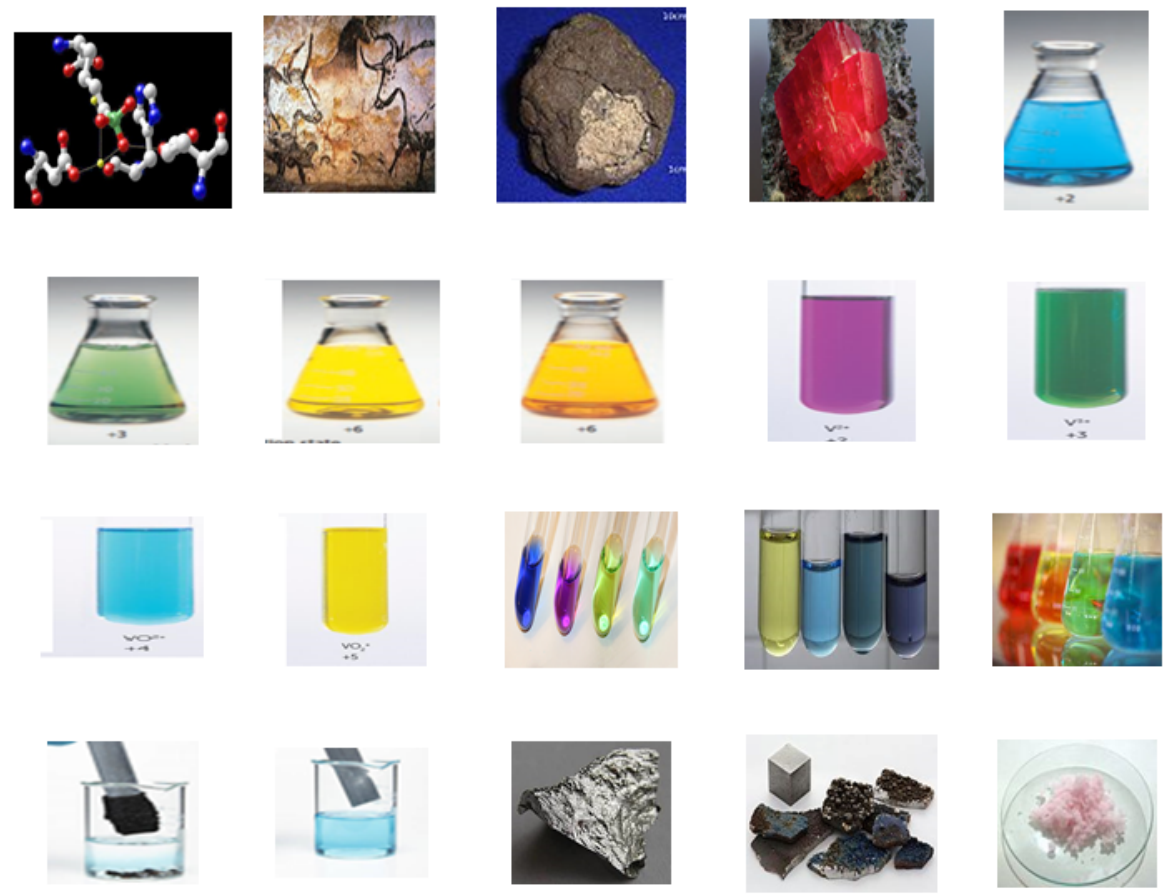

Figure 3 Spectrum of Magnisium

\section{Recapitulation}

1. In the present experiment name the reducing agent that donates the electron in the redox reaction? Glucose $-\mathrm{C}_{6} \mathrm{H}_{12} \mathrm{O}_{6}$

2. Name the oxidizing agent which gains electrons? Permanganate ion $\mathrm{MnO}_{4}{ }^{-}(a q)$ is the first oxidizing agent and after that electros are donated to manganate ion.

3. Does the potassium permanganate in the solution absorb frequencies of electromagnetic radiations from visible light that corresponds to the colour green as in seen or its complementary colour red?

Potassium permanganate absorbs from red part of the visible spectrum but we see the complementary colour green of manganic ions.

4. Name any chemical element that exhibit variable oxidation state in the solution? 


\begin{tabular}{|c|c|c|c|c|}
\hline Sl. No & Element & Variable oxidation state & \multicolumn{2}{|c|}{ Colour } \\
\hline \multirow[t]{2}{*}{1} & Chromium & $\mathrm{Cr}_{2} \mathrm{O}_{72}-$ & Orange & \\
\hline & & $\mathrm{Cr}_{2} \mathrm{O}_{4}^{-2}$ & Yellow & \\
\hline \multirow[t]{4}{*}{2} & Vanadium & $\mathrm{V}^{+2}$ & Violet & \\
\hline & & $\mathrm{V}^{+3}$ & green & \\
\hline & & $\mathrm{VO}^{+2}$ & Blue & \\
\hline & & $\mathrm{VO}_{4}-3$ & Yellow & \\
\hline
\end{tabular}

5. What are the uses of manganese in biology and industry?

1. It is used in batteries, stainless steel, fuel, additives and pigments

2. It is also used as a significant cofactor for many enzymes such as photosystem II in chloroplast.

3. It is toxic to human in excess

\section{Variations in the experiment}

The experiential learning activity for experimental redox reaction may be conducted by using chewing gum containing sugar as a reducing agent in place of adding sugar to the flask. Students can also use plastic bottle and shake well to observe the colour change fig 5 . Both students and teachers may be innovative and creative for giving more ideas for experimental learning activities.

\section{Statement of the problem}

In the present paper attempt is made to investigate the impact of experiential learning activity designed for experimental redox reaction on the academic achievement among senior secondary school students in the subject Chemistry. Hence the statement of the problem is entitled as "Outcome based learning: the effect of experiential learning activities on the attainment of specific learning outcome among Senior Secondary School students".

\section{Purpose of the study}

The purpose of the present paper is to investigate the effectiveness of experiential learning activity designed for experimental redox reaction on students' interest and 

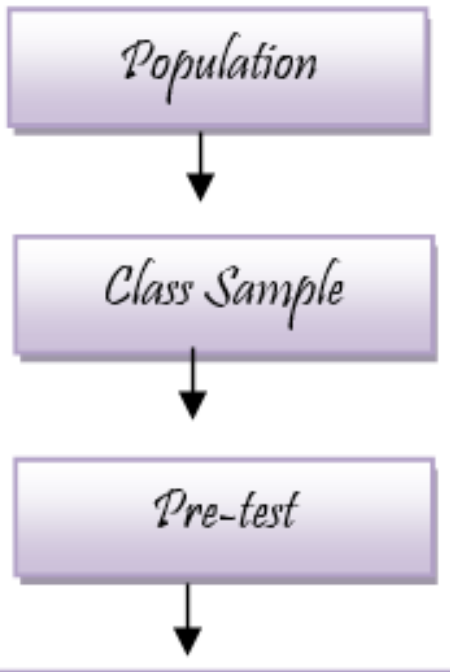

\section{Examination of Students}

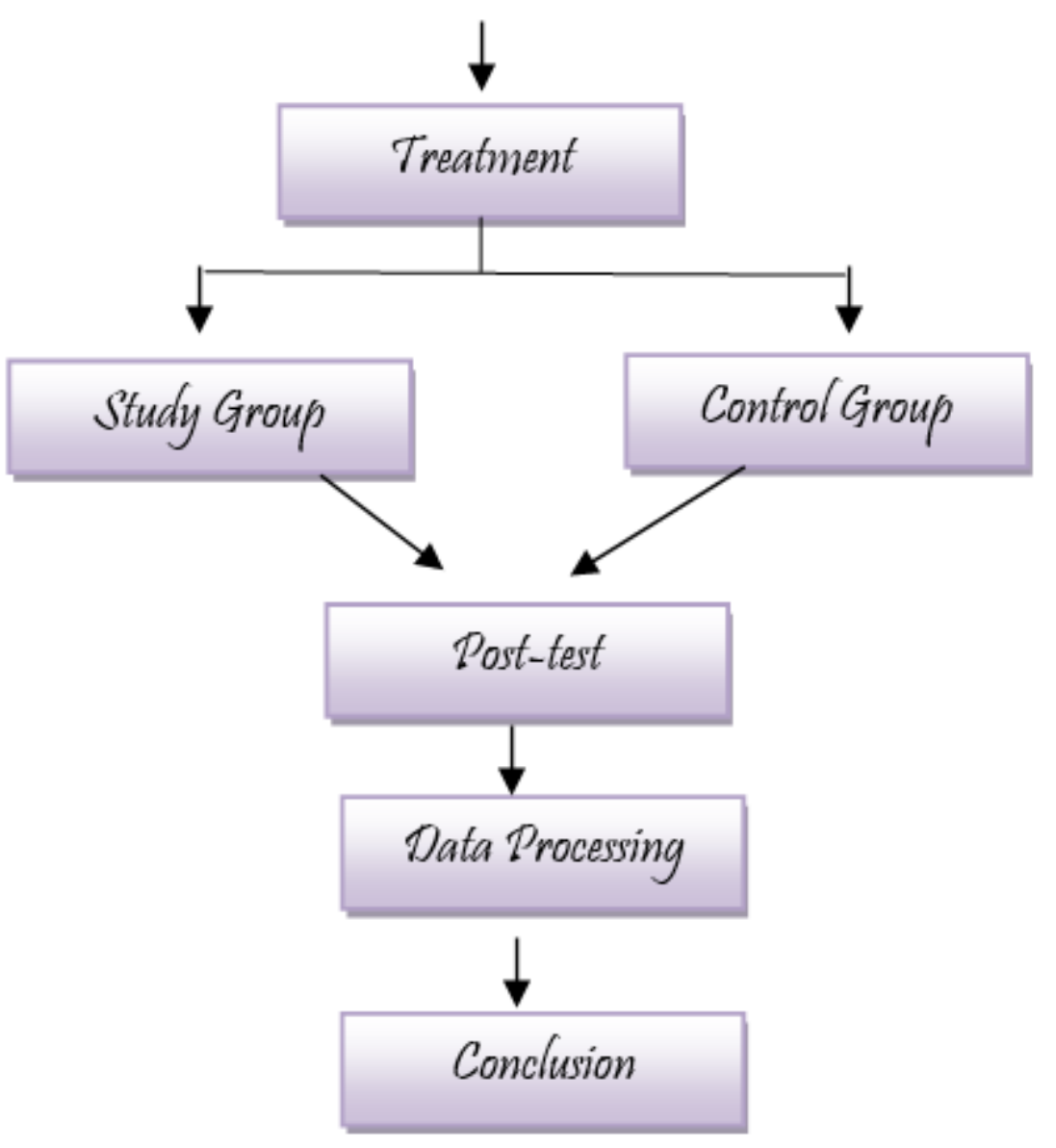

Figure 4 Sample Research Procedure 
their academic achievement in Chemistry.

\section{Research questions}

The following research question are framed to guide the study

1. How does the teaching learning with and without experiential learning activities affect the students' interest in subject?

2. How does students' interest affect their academic performance?

\section{Hypothesis}

Following postulated hypothesis are applied in the study:

$\mathbf{H}_{0}$ 1: There is no noteworthy difference in the interest among the learners' taught with and without experiential learning activities.

$\mathbf{H}_{0}$ 2: Interest of the learners does not have any noteworthy relation to their academic achievement in the subject.

\section{METHODS}

\section{Research design}

Mix research design is employed in the present study. Quasi experimental research design is employed for the present study. Ex-facto design is used to investigate the interest of the students.

\section{Population of the study}

All students studying Chemistry as elective subject at senior secondary school level.

\section{Sample:}

Totally 50 students participate in the study. Random sampling technique is applied to select the sample. Sample is divided into two groups: study group and control group. Each group consists of 25 students. Students of the study group are exposed to the experiential learning activities extended to the traditional chalk and talk method. But students of control group are exposed only to chalk and talk method.

\section{Tool}

Data is collected by using questionnaire. Two questionnaires are developed by the researcher. First, Subject Interest Test (SIT) consists of 10 items using 4 Likert scale. The tool is validated by experts in test and measurements. It is also subjected to Cronbach Alpha reliability test and found to be 0.86 . Next, Chemistry Performance Test (CPT) consists of 20 MCQ questions and it has four distractors with one correct answer. Tool is subjected to Richardson's formula and the result is 0.76 .

\section{Data analysis}

Data is analyzed by using descriptive static tools. 
Table 1 Independent t-test difference between the students of study group and control group

\begin{tabular}{lllll}
\hline Variables & N & Mean & Std & t-Cal \\
$\begin{array}{l}\text { Redox reaction taught by } \\
\text { using Experiential Learn- }\end{array}$ & 25 & 34.46 & 4.28 & 4.61 \\
$\begin{array}{l}\text { ing Activity } \\
\begin{array}{l}\text { Redox reaction taught } \\
\text { without using Experien- }\end{array}\end{array}$ & 25 & 25.90 & 7.06 & \\
tial Learning Activity & & & \\
\hline
\end{tabular}

\section{RESULT AND DISCUSSIONS}

Pearson Product Moment correlation coefficient analysis of relationship between academic performance and learner's interest when taught by using Experiential Learning Activity

Table 2 PearsonProduct Moment correlation coefficient analysis of relationship betweenacademic performance and learner's interest when taught by using ExperientialLearning Activity

\begin{tabular}{cccccc}
\hline Variables & $\sum \mathbf{x}$ & $\sum \mathbf{x} 2$ & $\sum \mathbf{x y}$ & $\mathrm{R}$ & $\mathrm{R}-\mathrm{Cal}$ \\
& - & - & & & \\
& $\sum \mathbf{y}$ & $\sum \mathbf{Y 2}$ & & & \\
Academic performance & 1759 & 9870.32 & 4166.22 & 0.877 & 0.69 \\
\hline Interest & 1105 & 2501.71 & & & \\
\hline
\end{tabular}

Result of Table 1 reveals that the calculated t value 4.61 is greater than the critical $t$ value (2.02). It is revealed from the result that there is noteworthy difference and so the null hypothesis $\mathrm{H}_{0} 1$ "There is no noteworthy difference in the interest among the learners' taught with and without experiential learning activities" is rejected. The interest of the students can be enhanced by using experiential learning activities.

In such micro less during of 45 minutes students of the study group are exposed to the experiential learning activity designed for the experimental redox reaction. Before conducting the experiment, the topic is taught by using traditional chalk and talk method for both the study and the control group. But the study group is exposed to experiential learning activity and hand-outs are distributed before the experiment. After the experiment Subject Interest Test is administrated to both the groups. Chemistry Performance Test (CPT) is administrated the next day.

Result of table two reveals that the calculated $r$ value 0.87 is greater than critical $r$ value 0.07 given 48 degree of freedom at 0.05 alpha level. It shows that there is a noteworthy relation between the academic performance and the interest of the learner. Hence the null hypothesis $\mathrm{H}_{o} 2$ : "Interest of the learners does not have any noteworthy relation to their academic achievement in the subject" is not accepted. The result of the study reveals that academic achievement depends upon the interest of the students in the subject. Hence it implies that the students having high interest in the subject have high academic performance. 


\section{Oxidation states of Manganese}

\begin{tabular}{|l|l|l|l|}
\hline $\begin{array}{l}\text { Oxidation } \\
\text { State }\end{array}$ & Crystal & \multicolumn{2}{|c|}{ Colour } \\
\hline+2 & $\mathrm{MnCl}_{2}, \mathrm{MnCO}_{3}, \mathrm{MnO}$ & Dark pink & \\
\hline+3 & $\mathrm{MnF}_{3}, \mathrm{Mn}(\mathrm{OAc})_{3}, \mathrm{Mn}_{2} \mathrm{O}_{3}$ & Purple red & \\
\hline+4 & $\mathrm{MnO}_{2}$ & Brown/black & \\
\hline+5 & $\mathrm{~K}_{3} \mathrm{MnO}_{4}$ & & \\
\hline+6 & $\mathrm{~K}_{2} \mathrm{MnO}_{4}$ & Dark green & \\
\hline+7 & & Light green & \\
\hline
\end{tabular}

\section{CONCLUSION}

Experiential learning holds lot of fun experiments to expand, enhance and magnify the imagination of the learners. Experiential learning activity germinates joy full learning experience amongst the learners and kindles their interest in Chemistry to attain the specific learning outcome. Teachers put efforts to make teaching learning instructions joyful. Experiential learning activities stimulate the interest in the subject. Result of the present investigation demonstrates that there is a positive relationship between students' interest in the subject and their academic performance. Students' academic achievement depends on students' interest and motivation level. The learners who excel in their academic performance have high level of interest and motivation. Low interest and low motivation acts as a barrier for achieving high performance level in the academics. High motivation level and interest also enhances their active participation in class room instructions which contribute to their higher academic achievement. Most of the hand-on activities are not mind-on activities. So, 
experiential learning activities are planned effectively. Result analysis reveals that the students' scores are consistently high in their academics when they have high interest and motivation level to learn the subject. Inventions are the products of the interested brain. Interest and motivation are the noteworthy factor to enhance the active participation in class room instructions. The subject like Chemistry requires experiential learning activities that can transform topic, content and concept to concreate learning and it provides learners with high motivational level to use the learners' intellectual ability to attain intended learning outcome. Hence the present paper reveals that experiential learning activities not only enhance the interest in the subject but enhance the students' academic performance.

\section{REFERENCES}

Thote, P. (2019). Experiential Learning: Inclusive Art Education for Joyful Learning, 8, 9-9.

Thote, P., \& Learning, E. (2019). Model for Teaching Science at Grade Nine. Research Magma, $3(06)$.

Thote, P., \& S, G. (2020a). AN ANALYSIS OF IMPACT OF EVIDENCE BASED LEARNING ON ACADEMIC ACHIEVEMENT OF STUDENTS. International Journal of Research -GRANTHAALAYAH, 8(8), 207-216. Retrieved from https://dx.doi.org/10.29121/ granthaalayah.v8.i8.2020.869 10.29121/granthaalayah.v8.i8.2020.869

Thote, P., \& S, G. (2020b). EVIDENCE BASED LEARNING: AN ANALYSIS OF IMPACT ON RETENTION OF KNOWLEDGE. International Journal of Research -GRANTHAALAYAH, 8(10), 224-235. Retrieved from https://dx.doi.org/10.29121/granthaalayah.v8.i10 .2020 .1883 10.29121/granthaalayah.v8.i10.2020.1883

Thote, P., \& S, G. (2020c). EXPERIENTIAL LEARNING: AN ANALYSIS OF IMPACT ON ACADEMIC ACHIEVEMENT AMONG STUDENTS OF GRADE 12. International Journal of Research -GRANTHAALAYAH, 8(9), 188-199. Retrieved from https://dx.doi.org/10 .29121/granthaalayah.v8.i9.2020.1337 10.29121/granthaalayah.v8.i9.2020.1337

Thote, P., \& S, G. (2020d). OUTCOME BASED LEARNING: AN ANALYSIS OF IMPACT ON ACADEMIC ACHIEVEMENT AMONG SCHOOL STUDENTS. International Journal of Research -GRANTHAALAYAH, 8(11), 89-94. Retrieved from https://dx.doi.org/10 .29121/granthaalayah.v8.i11.2020.2222 10.29121/granthaalayah.v8.i11.2020.2222

Thote, P., \& S, G. (2021a). EVIDENCE BASED LEARNING: AN ANALYSIS OF IMPACT OF EXPERIENTIAL LEARNING ON ATTAINMENT OF INTENDED SPECIFIC LEARNING OUTCOME. International Journal of Research -GRANTHAALAYAH, 9(1), 6674. Retrieved from https://dx.doi.org/10.29121/granthaalayah.v9.i1.2021.2971 10 .29121/granthaalayah.v9.i1.2021.2971

Thote, P., \& S, G. (2021b). EVIDENCE BASED LEARNING: AN ANALYSIS OF IMPACT OF REMEDIAL TEACHING ON CONCEPTUAL UNDERSTANDING. International Journal of Research -GRANTHAALAYAH, 8(12), 211-224. Retrieved from https://dx.doi.org/10 .29121/granthaalayah.v8.i12.2020.2606 10.29121/granthaalayah.v8.i12.2020.2606

Thote, P., \& S, G. (2021c). EVIDENCE BASED LEARNING: AN ANALYSIS OF IMPACT OF TEACHER'S DESIGN MODEL ON CONCEPTUAL UNDERSTANDING. International Journal of Research -GRANTHAALAYAH, 9(3), 71-77. Retrieved from https://dx.doi.org/ 10.29121/granthaalayah.v9.i3.2021.3702 10.29121/granthaalayah.v9.i3.2021.3702

Thote, P., \& S, G. (2021d). EVIDENCE BASED LEARNING: A STUDY OF IMPACT ON 
EXPERIENTIAL LEARNING ACTIVITIES ON ATTAINMENT OF SPECIFIC LEARNING OUTCOMES. International Journal of Research -GRANTHAALAYAH, 9(2), 2231. Retrieved from https://dx.doi.org/10.29121/granthaalayah.v9.i2.2021.3225 10 .29121/granthaalayah.v9.i2.2021.3225 